
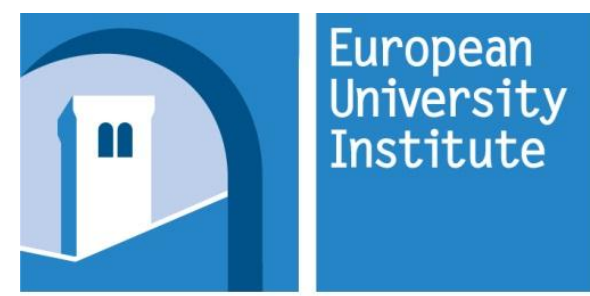

ROBERT

SCHUMAN

CENTRE FOR

ADVANCED

STUDIES

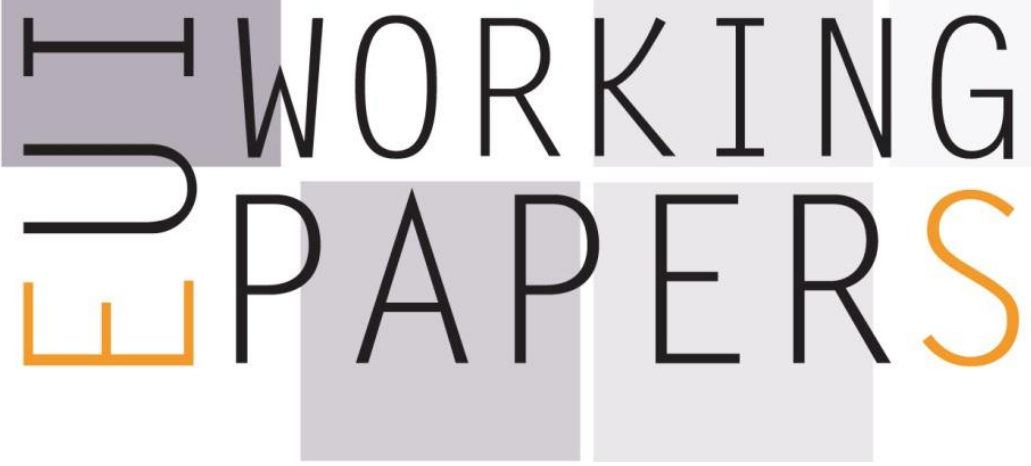

RSCAS 2014/02

Robert Schuman Centre for Advanced Studies

EUDO - European Union Democracy Observatory

Trans-nationalising Europe's Voting Space

Jonathan Bright, Diego Garzia, Joseph Lacey and Alexander H. Trechsel 

European University Institute

Robert Schuman Centre for Advanced Studies

EUDO - EUROPEAN UNION DEMOCRACY OBSERVATORY

\section{Trans-nationalising Europe's Voting Space}

Jonathan Bright, Diego Garzia, Joseph Lacey and Alexander $\mathrm{H}$. Trechsel

EUI Working Paper RSCAS 2014/02 
This text may be downloaded only for personal research purposes. Additional reproduction for other purposes, whether in hard copies or electronically, requires the consent of the author(s), editor(s). If cited or quoted, reference should be made to the full name of the author(s), editor(s), the title, the working paper, or other series, the year and the publisher.

ISSN 1028-3625

(C) Jonathan Bright, Diego Garzia, Joseph Lacey and Alexander H. Trechsel, 2014

Printed in Italy, January 2014

European University Institute

Badia Fiesolana

I - 50014 San Domenico di Fiesole (FI)

Italy

www.eui.eu/RSCAS/Publications/

www.eui.eu

cadmus.eui.eu 


\section{Robert Schuman Centre for Advanced Studies}

The Robert Schuman Centre for Advanced Studies (RSCAS), created in 1992 and directed by Brigid Laffan since September 2013, aims to develop inter-disciplinary and comparative research and to promote work on the major issues facing the process of integration and European society.

The Centre is home to a large post-doctoral programme and hosts major research programmes and projects, and a range of working groups and ad hoc initiatives. The research agenda is organised around a set of core themes and is continuously evolving, reflecting the changing agenda of European integration and the expanding membership of the European Union.

Details of the research of the Centre can be found on:

http://www.eui.eu/RSCAS/Research/

Research publications take the form of Working Papers, Policy Papers, Distinguished Lectures and books. Most of these are also available on the RSCAS website:

http://www.eui.eu/RSCAS/Publications/

The EUI and the RSCAS are not responsible for the opinion expressed by the author(s).

\section{European Union Democracy Observatory (EUDO) Working Paper Series}

The European Union Democracy Observatory (EUDO) was launched in the spring of 2006 as an independent and interdisciplinary academic organization. In 2008, EUDO became a fully-integrated part of the Robert Schuman Centre for Advanced Studies (RSCAS). Its declared goals are: to produce a permanent and periodic assessment of democratic practices within the EU; to serve as a forum to exchange ideas and good practices; and to be a resource for policy-makers, academics and EU citizens.

EUDO focuses its activities around the themes of the four EUDO Observatories, which form the backbone of EUDO and constitute its main organizing principle. They are responsible for data and documentation gathering and are directed by EUI internal professors in conjunction with external EUDO experts. Each Observatory coordinates specific research projects. The four Observatories are: the Observatory on Public Opinion, Political Elites and the Media, the Observatory on Political Parties and Representation, the Observatory on Institutional Reform and Change, and the Observatory on Citizenship.

The EUDO working paper series started in December 2009 and aims at disseminating high-quality research on the above-mentioned issues. Not only the directors of the Observatories, but as well EUDO fellows and external experts as well as other scholars and practitioners are welcome to submit their work to the series.

For further information:

www.eudo.eu

Robert Schuman Centre for Advanced Studies

European University Institute

Via delle Fontanelle 19

50014 San Domenico di Fiesole

Firenze, Italy

EUDO.secretariat@eui.eu 



\begin{abstract}
Building on MEP Andrew Duff's proposal to create a limited pan-European constituency for electing representatives to the European Parliament, this paper argues that there are good reasons for believing that such an institution would better be built around national parties rather than Europarties as they currently exist. Using data from a Voting Advice Application (VAA), the EU Profiler, we demonstrate that the overwhelming majority of individuals who used this device would be better represented in the European Parliament, in terms of their policy preferences, if they could vote for a party from a different member state than their own. Furthermore, we find that there is significant active demand to be able to vote in this manner, and that such demand is positively correlated with citizens who found that they would be better represented given the opportunity to vote transnationally. Ultimately, we argue that a transnational electoral constituency administered by a VAA that could match individuals with the closest partisan offer in Europe would not only improve the level of representation in the EP but also contribute to forging deeper transnational links in the EU.
\end{abstract}

\title{
Keywords
}

e-Democracy, EU elections, Representative Deficit, Voting Advice Applications. 



\section{A polity of ignorance}

Our aim in this paper is to suggest a way in which Europe's voting space could be modified in order to bring about a more transnational dimension to European politics. We can show that by transnationalising Europe's voting space, allowing citizens to vote beyond their national borders in elections to the European Parliament [EP], opportunities for better democratic representation would arise. Moreover, when individual citizens are personally made aware of these opportunities for improved representation at the European level, a large number will actively seek to vote in the newly proposed transnational constituency rather than their familiar national districts. We argue that a transnational voting space, coupled with citizens' active demand for the electoral opportunities it affords, may result in greater horizontal or transnational engagement between citizens of the European polity.

Our starting point is the European voting space. A voting space has been defined as 'the totality of procedural devices employed by a democratic community that formally open up the main institutions of political decision-making to the input of individual citizens through the ballot' (Lacey 2013). It is, in other words, the explicit legal basis that specifies not only the conditions under which particular votes can and must take place but also the precise sense in which particular institutions are related to voting procedures. Europe's voting space first became a reality in 1979 when the 1976 'Act concerning the election of the representatives of the Assembly by direct universal suffrage' was implemented by way of allowing all eligible citizens in the European Community's member states the right to elect representatives to the Assembly (now the EP).

There are a great number of ways in which a voting space can be legally articulated and procedurally arranged which will in turn have consequences for how politics and political discourse is conducted. Notwithstanding its achievements, Europe's voting space has been widely criticised as being inadequately designed given the nature of the polity it faces. Here we highlight two key problems: the European polity is both state-centric and lingua-centric. From the perspective of a voting space, state-centrism means that national parties primarily campaigning on national issues will likely dominate European elections such that supranational issues are side-lined and EU institutions are left largely invisible to the average citizen (Mair 2000). This is primarily due to the "second order character" adherent to European elections, a qualification on which much ink has been spilt since its branding by Reif \& Schmitt (1980; cf. Hix and Marsh 2011). A consequence of this is that MEPs who are attached to national parties and who have been elected on national issues are primarily representing voters in their respective countries even though they are theoretically capable - and normatively encouraged - to represent any voter in the Union supporting the party's political program. Lingua-centrism means, in Will Kymlicka's terms (2001), that European politics is overwhelmingly politics in the vernacular. That is to say, the peoples of Europe engage politically in their own linguistically demarcated public spheres, which thereby prohibits the formation of a common European discourse. Taken together, Europe's state and lingua-centrism result in a relative polity of ignorance where citizens from different member states lack an understanding of each other's perspectives and the issues and institutions that functionally bind them together.

Proposals abound with at least a partial focus on addressing the kind of problems facing the European polity of ignorance. Typically, a connection is made between improving the quality of representative democracy in the EU so that the level of citizen involvement in the wider political process increases. Popular proposals include politicising the EU in competitive fashion by linking the outcome of the elections to some kind of "government formation" such that the EP is viewed as a more consequential institution by both voting citizens and their representatives (e.g. Hix 2008; Lacey 2013). An alternative route, which has been less explored, is to allow voters to choose from candidates within a transnational electoral district. British MEP Andrew Duff (2010), writing on behalf of the EP's Committee on Constitutional Affairs, presents a persuasive case for the latter kind of 
arrangement. He recommends a modification of Europe's voting space such that 25 representatives are elected by the citizens of Europe at large. This pan-European electoral district would be an addition to the EP's existing 751 seats which are divided among member states, each of which forms its own electoral district for electing MEPs. On Duff's view, the overall effect of his proposal would be to add an important Euro-centric dimension to EP elections while giving a greater role to European political parties who would take the lead in campaigning across the transnational electoral district. Though we find this proposal intriguing as an achievable goal for improving the democratic quality of Europe's voting space, its emphasis on the role of Europarties in managing a transnational electoral district of this kind may not be the ideal arrangement from the perspective of representing the citizens of Europe. The extent to which the interests and values of individual citizens are made present in government is the forerunning criterion for good democratic representation (Pitkin 1967, Young 2000, Urbinati 2006, Vieira and Runciman 2008). Yet Europarties are essentially federations of national parties whose capacity to represent citizens in an optimal manner may be easily called into question to the extent that their policy platforms are often the vaguely stated results of protracted compromises leading to lowest common denominator policy positions.

We suggest an alteration to Duff's proposal that would place national rather than European political parties in competition for the suggested transnational electoral district. As we hope to demonstrate, the opportunity for electors to vote for any national party running in European elections outside their national context could lead to a significant improvement in the quality of democratic representation. Our line of argumentation relies on extensive data from a transnational, large-scale tool that was developed in view of the 2009 European Parliamentary Elections: the EU Profiler. This is an Internet based Voting Advice Application (VAA) aimed at revealing to its users the structure of the political landscape as shaped by political parties in their respective member states and, crucially, across the entire EU. We find that the majority of individuals who used the EU Profiler are potential "party migrants" insofar as their degree of closeness to the partisan offer would be increased were they able to vote for a party outside of their national district. Furthermore, we find that there is noteworthy active demand among citizens for a transnational voting space of this kind and that this demand is correlated with the perception that a transnational voting space could improve their quality of representation.

A VAA like the EU Profiler, however, is not just a rich data source for testing hypotheses: it is also a necessary feature of a transnational voting space that would allow citizens to vote for parties outside their nationally defined districts. There are two reasons for this. First, due to the sheer number of national parties involved in elections to the EP, voters will require some means by which to narrow down their range of electoral options. Second, as a consequence of Europe's formidable linguistic diversity, there will be inevitable communicative problems disincentivising transnational electoral campaigns. A VAA device, documenting party positions and translated into all relevant languages, would be necessary to make transnational campaigning possible while offering prospective voters salient information about national political parties running in the transnational voting space.

A transnational voting space organised in the manner we have proposed would not only likely improve the quality of representation in the EP but also add a unique Euro-centric dimension to the electoral process that mitigates the state- and lingua-centric properties of the European polity. By allowing for the electoral connection between any EU citizen and any EP candidate, we may increase the degree of deliberative engagement between member state public spheres. Essentially, the accessibility of all European party policy positions to all citizens, via the multilingual VAA, presents citizens with the opportunity to engage with and attach themselves to a national party that is discursively rooted in a different public sphere. Once candidates are elected in the transnational voting space, the extensive translation service at the disposal of the EP offers the possibility for these MEPs to address citizens of the EU at large. At the same time, this service allows citizens to keep track of their chosen candidate just as they could an MEP elected in a national voting space. 
We begin with a description of the EU Profiler project and explain how it operated in the 2009 European Parliamentary Elections (section 2). In this section we also formalise our main hypotheses concerning the representative benefits of trans-nationalising Europe's voting space and the active demand of some citizens for the implementation of such a voting space. Following this, we test our hypotheses against the data derived from the EU Profiler project (section 3). Finally, section 4 concludes.

\section{Transnational representation in the Internet age: a proposal}

Voting Advice Applications have nowadays turned into a widespread feature of electoral campaigns in Europe and beyond (Cedroni and Garzia, 2010; Trechsel and Mair, 2011; Garzia, Trechsel, Vassil \& Dinas, 2013). Although different in some respects, VAAs share a common underlying principle: they help users in their act of making a party choice and casting a vote by comparing their policy preferences on major issues with the programmatic stances of political parties on the same issues. The core of every VAA that enables this comparison is a list of political issue statements formulated by the body that created the VAA e.g., "social programs should be maintained even at the cost of higher taxes". Each user can express her agreement or disagreement with each particular statement (see Figure 1, above). The resulting issue preferences of the user are then matched with the positions of the parties on these same issues. After comparing the user's profile with that of each party, the application produces a "voting advice", usually in the form of a rank-ordered list, at the top of which stands the party closest to the user's policy preferences (see Figure 1, below).

Figure 1. Example of a VAA statement (above); The 'voting advice' provided in the results screen (below)

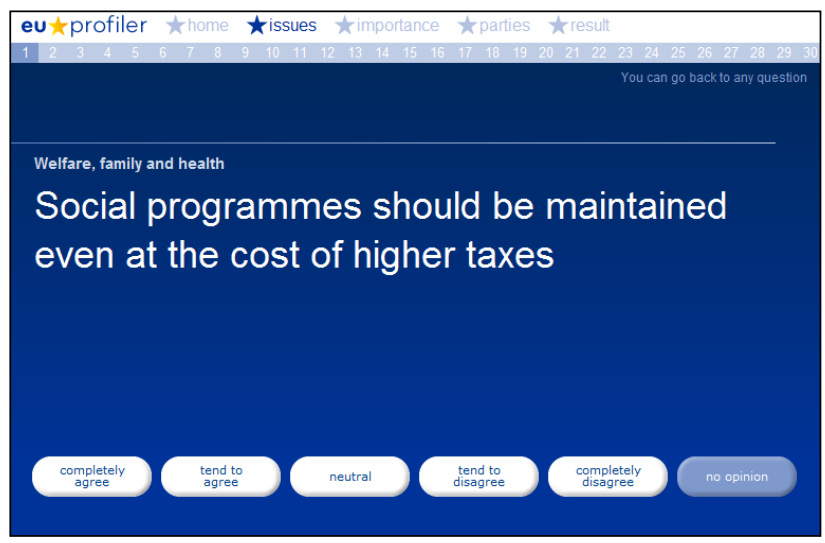

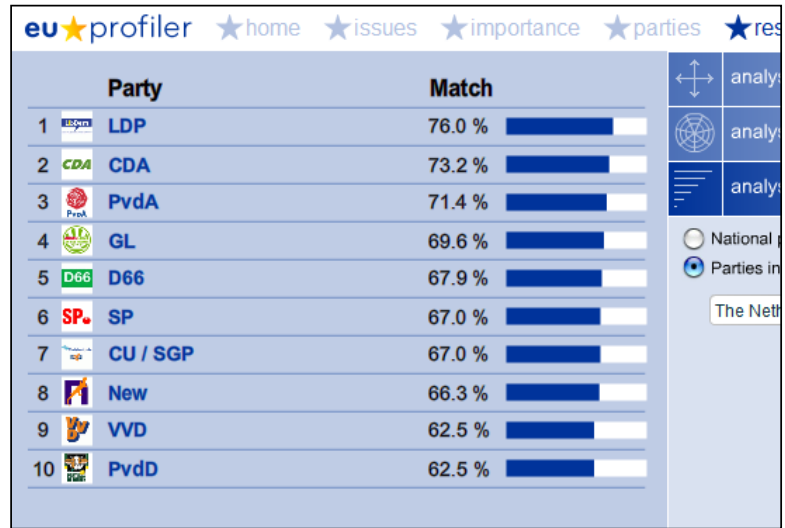


A recent assessment of the spread of VAAs mapped the presence of (at least) one such tool in all but two countries of the EU27 (Garzia and Marschall, 2012). In some countries - including the Netherlands, Germany, Switzerland, Finland, and Belgium - the incorporation of VAAs into the electoral process is almost self-evident and in several instances citizens are offered competing tools during the same election campaign. In the run-up to the 2012 parliamentary election in the Netherlands, 4.9 million users resorted to the Dutch VAA StemWijzer. In absolute numbers, the German Wahl-O-Mat launched before the federal elections in 2009 has been used by 6.7 million users (Marschall and Schmidt 2010), a figure that almost doubled in the 2013 German federal elections: the tool reached largest number of users ever (around 12.3 million).

VAAs are not limited to the national level. For the 2009 European Parliamentary Elections, a panEuropean VAA was developed under the auspices of the European University Institute. In the present context, several features of the EU Profiler should be noted. First, political parties across the entire European Union, competing for seats in the European Parliament, were coded within 30 policy areas. Second, users had access to documents that verified the positions assigned to parties on the different issues and were able to indicate saliency by attributing different weights to each issue. Third, and most importantly to our purposes, users could not only compare their own positions with those of the political parties running in their respective electoral contexts - usually the user's country of residence - but with all 274 political parties running in the 2009 European Parliamentary Elections and included in the EU Profiler. Over 2.5 million unique users visited the website during the six weeks prior to the June 2009 elections, with almost one million complete voting advices generated. The data on parties' and users' issue positions is complemented by a user-survey that investigates extensively the sociodemographic characteristics and the political attitudes of a selected sample of users (for more details see Trechsel \& Mair, 2011; Alvarez, Levin, Trechsel \& Vassil, 2013).

The EU Profiler project offers a large playground for empirically measuring the qualitative improvement of representation in a virtual, transnational voting space. A pan-European VAA provides for technological innovations "translating" the policy positions of political parties into all relevant languages. The positions are based on a set of identical and therefore comparable issues on which all parties, independently of their national anchoring, take a stance. This is exactly what the EU Profiler proposed by pushing a form of "indirect campaigning" across the entire continent (Garzia, Trechsel, Vassil \& Dinas, 2013). Users were able to compare their views not only with their national political offer but with all parties running in the elections and included in the tool.

Central to this contribution is the degree of congruence between citizens and political parties. From the point of view of individual representation, the stronger this congruence, the more accurate becomes, potentially, the ability of parties to represent the views of their voters. This congruence is typically reported back to the user of a VAA, by producing a list of parties ranked from the best matching to the worst. Alvarez, Levin, Mair and Trechsel (2013) developed the concept of "representative deficit" from the degree to which users fail to match the political supply: the lower the match between the user's issue preferences and the parties' offer, the higher the representative deficit. Although citizens' votes still have to be cast within their respective national contexts, the EU Profiler allowed users to match their preference with any party in Europe, therefore producing a list of best to worst matching parties across the entire continent. Thanks to these data we will therefore be able to measure to what extent users find a better matching party outside their national voting district.

For deriving our main hypothesis guiding our empirical investigation we make use of a market analogy. On a market model the more varied, diverse and assorted is the offer of a product, the more likely a customer will be able to match her demands with the offer. Take for example a car company: if it produces only one model of car with the same colour and the same kind of engine the probability of matching this model with the wants and needs of a large number of customers is much lower than if the company offered a multitude of models from which to choose. Diversity in the offer should lead, theoretically, to a higher probability of fully satisfying customers' desires. A typical consumer, however, can only process and consider so many available options and in cases of great diversity will 
require some medium (whether a car salesman or an internet search engine) to narrow down his choices to those that best match his preferences. Let us apply this analogy to electoral politics. Theoretically, the more diverse the partisan offer at the polls, the higher the probability for voters to find a party matching their preferences better than in the context of a more reduced partisan offer. In other words, a voter's partisan representation - if measured by the degree of congruence between the voter and a party - can be improved when greater partisan diversity is on offer. A larger diversity of parties should therefore lead to a lowering of the average representative deficit so long as there is some reliable medium that could guide voters towards those party platforms that resonate most with their interests and values. Thus, our first hypothesis (H1) can be formulated as follows:

H1: The more diverse the partisan offer, the higher the probability for a voter to see her representative deficit reduced. Consequently, the average representative deficit for voters will be higher if they are confined to their national voting districts than if they were able to choose from the entire set of parties running in European Parliamentary Elections.

Our second hypothesis is an attempt to explaining why, if at all, users of the transnational VAA might be inclined to cast a vote for a party beyond their respective national confines. We believe that the readiness for a user to want to cast such a "transnational vote" is linked, again, to the representative deficit. Thus, our second hypothesis $(\mathrm{H} 2)$ reads as follows:

H2: The larger the reduction of the representative deficit, the higher the probability of a transnational $V A A$ user to want to cast a vote for a party competing in a country different from the one of the user.

In the following section we will test these two hypotheses empirically.

\section{Party migrants and active demand}

In a first step we create a variable measuring the representative deficit for each user, both within her national voting district and in the European voting space. This variable ranges from 0 to 100 percent and corresponds to the distance between a potential perfect overlap of 100 percent and the real extent of overlap between the best-matching party "on offer" and the user's preferences, as shown to the user in the match-list visualization of the EU Profiler. The smaller the representative deficit, therefore, the better the policy congruence between the best-matching party in a given voting space and a VAA user's preferences. As an example, Figure 2 reports the voting advice provided to a fictional user comparing her positions with the respective national parties only (above) and with all the parties running in the EP election (below). 
Figure 2. Measuring the rep. deficit in a national (above) and a transnational (below) voting district

\begin{tabular}{|c|c|c|c|c|c|c|}
\hline \multicolumn{3}{|c|}{ Party } & Match & $\stackrel{\uparrow}{\longleftrightarrow}$ & analyse your position & (?) \\
\hline 17 & \multicolumn{2}{|l|}{ New } & $72.5 \%$ & $\theta$ & analyse your nearest party & $?$ \\
\hline $2 \Rightarrow$ & \multicolumn{2}{|l|}{ CU / SGP } & $65.8 \%$ & & \multirow{2}{*}{ analyse party matches } & \\
\hline 3 & GL & & 65.8 & $\overline{\overline{\bar{E}}}$ & & \\
\hline 4 Prod & PvdA & \multirow{2}{*}{$\begin{array}{l}\text { Representative Deficit }= \\
100-72.5=\underline{\mathbf{2 7 . 5}}\end{array}$} & 4.2 & \multirow{2}{*}{\multicolumn{2}{|c|}{$\begin{array}{l}\odot \text { National parties } \\
\text { Parties in Europe }\end{array}$}} & \\
\hline \multirow[t]{2}{*}{5 एस्दुता } & LDP & & $63.0 \%$ & & & \\
\hline & \multicolumn{2}{|l|}{ Party } & Match & & analyse your position & \\
\hline 1 & \multicolumn{2}{|l|}{ EDP } & $77.5 \%$ & 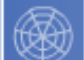 & analyse your nearest party & $?$ \\
\hline 2 MKK & \multicolumn{2}{|l|}{ SMK } & $75.0 \%$ & & \multirow{2}{*}{ analyse party matches } & \\
\hline $3 \underset{\text { sfp }}{7}$ & \multicolumn{2}{|l|}{ RKP } & $75.0 \%$ & $\overline{\overline{\overline{-}}}$ & & \\
\hline $4 \overline{8}$ & дн & \multirow{2}{*}{$\begin{array}{l}\text { Representative Deficit = } \\
100-77.5=\underline{\mathbf{2 2 . 5}}\end{array}$} & & \multirow{2}{*}{\multicolumn{2}{|c|}{$\begin{array}{l}\odot \text { National parties } \\
\odot \text { Parties in Europe }\end{array}$}} & \\
\hline 5 상 & TKP & & $73.2 \%$ & & & \\
\hline
\end{tabular}

The mean value of the national representative deficit for the whole sample of $E U$ Profiler users is 27.6 per cent $(n=473$ '045) - that is, on average, users' best matching party in their national constituency leaves about a quarter of their political preferences unrepresented. In Table 1 we present the average value of EU Profiler users' representative deficit broken down by their country of residence. 
Table 1. Average Representative Deficit in National Voting Districts

\begin{tabular}{|c|c|c|c|c|c|}
\hline \multirow{2}{*}{$\begin{array}{l}\text { Country } \\
\text { Netherlands }\end{array}$} & \multicolumn{2}{|c|}{$\begin{array}{c}\text { Representative } \\
\text { Deficit }\end{array}$} & \multirow{2}{*}{$\begin{array}{l}\text { Country } \\
\text { Germany }\end{array}$} & \multicolumn{2}{|c|}{$\begin{array}{c}\text { Representative } \\
\text { Deficit }\end{array}$} \\
\hline & 22.78 & (4.9) & & 28.54 & $(5.7)$ \\
\hline Belgium & 23.33 & $(5.5)$ & Sweden & 28.56 & (6.4) \\
\hline Denmark & 23.78 & $(6.5)$ & Hungary & 28.76 & (5.3) \\
\hline Spain & 25.06 & (8.1) & Slovenia & 29.03 & $(6.2)$ \\
\hline Finland & 25.22 & (5.7) & Czech Republic & 29.07 & $(5.2)$ \\
\hline Luxembourg & 25.58 & (6.1) & Malta & 29.14 & (6.7) \\
\hline France & 25.92 & (6.3) & Estonia & 29.50 & $(5.0)$ \\
\hline Bulgaria & 26.31 & (5.4) & Portugal & 29.59 & $(5.2)$ \\
\hline Austria & 26.69 & (6.6) & Ireland & 31.61 & (6.0) \\
\hline Italy & 27.09 & $(5.1)$ & Romania & 33.13 & (4.8) \\
\hline EU27 & 27.55 & (7.2) & Slovakia & 35.38 & $(5.5)$ \\
\hline Greece & 27.56 & (5.9) & Lithuania & 39.61 & $(5.8)$ \\
\hline Cyprus & 28.07 & (5.2) & Latvia & 42.01 & $(5.2)$ \\
\hline United Kingdom & 28.18 & $(4.2)$ & Poland & 43.88 & (5.3) \\
\hline
\end{tabular}

Note: Cell entries are mean values of users' representative deficit by national voting district (i.e., country of residence). Standard deviations are in parentheses.

In those countries in which parties provide a comparatively better fit with users' preferences - i.e., in the Benelux, in Nordic countries, but also in Spain and France - we find values slightly below the EU 27 mean. At the opposite side of the table, we find mostly Eastern European countries such as Romania, Slovakia, Lithuania and Latvia. According to these data, the worst performing country is Poland, where an average user's best matching party leaves over 40 per cent of her preferences unrepresented.

Having assessed the average representative deficit per country for users constrained to their national voting district, let us now calculate the change in the representative deficit when we relax the condition regarding national borders. The results are rather striking: roughly 84 percent of all $E U$ Profiler users would be better off with a party running in the European Parliamentary elections but outside their own country. In other words, for a very large majority of EU Profiler users, a foreign party would represent them better - if representation is measured by the overlap of party and user 
preferences - than their top-ranking national party. We call these users potential party migrants. Table 2 shows their distribution across the European Union by Member State. The further down in the list, the higher the proportion of potential party migrants. At the top of the list we find party systems where users are, on average, better represented. Typically, this is the case in the Netherlands and Belgium with only 55 per cent and 68 per cent respectively of potential party migrants (though it should be noted in each case that this still represents a majority). Also above the EU27 average we find three countries that are geographically relatively scattered (Bulgaria, Denmark and Spain). Significantly, 22 out of 27 EU Member States have an average of potential party migrants that is higher than the EU average.

Table 2. Proportion of Potential Party Migrants per Country

\begin{tabular}{|c|c|c|c|c|c|}
\hline Country & Users (N) & $\%$ Migrants & Country & Users (N) & \% Migrants \\
\hline Netherlands & $81^{\prime} 010$ & $55 \%$ & Malta & 218 & $93 \%$ \\
\hline Belgium & $37^{\prime} 374$ & $68 \%$ & Germany & $53^{\prime} 595$ & $93 \%$ \\
\hline Bulgaria & 4’029 & $71 \%$ & Slovenia & 887 & $93 \%$ \\
\hline Denmark & $1 ’ 046$ & $83 \%$ & France & $23^{\prime} 413$ & $94 \%$ \\
\hline Spain & $13^{\prime} 777$ & $83 \%$ & Italy & $30 ’ 158$ & $94 \%$ \\
\hline EU27 & 473’045 & $84 \%$ & Hungary & $4^{\prime} 538$ & $95 \%$ \\
\hline Austria & 7’313 & $88 \%$ & Estonia & 893 & $96 \%$ \\
\hline Luxembourg & $1^{\prime} 653$ & $89 \%$ & United Kingdom & $17^{\prime} 587$ & $97 \%$ \\
\hline Sweden & $116 ’ 316$ & $89 \%$ & Ireland & $2 ’ 445$ & $99 \%$ \\
\hline Finland & $2^{\prime} 683$ & $90 \%$ & Poland & $20 ’ 816$ & $100 \%$ \\
\hline Cyprus & 770 & $91 \%$ & Romania & 925 & $100 \%$ \\
\hline Greece & $5^{\prime} 635$ & $91 \%$ & Latvia & 527 & $100 \%$ \\
\hline Czech Republic & 2’971 & $92 \%$ & Lithuania & 906 & $100 \%$ \\
\hline Portugal & $41 ' 144$ & $93 \%$ & Slovakia & 416 & $100 \%$ \\
\hline
\end{tabular}

At the bottom of the list we find five Eastern European countries: Poland, Romania, Latvia, Lithuania, and Slovakia. Rather impressively, we find that here every single user would be better represented by a party outside her country of residence. The East-West divide, however, is not perfect. The UK and Ireland for example are not far from the bottom of the list with only $1 \%$ of the respective sample being 
better off with a national party. Similarly, large Member States such as Germany ( 93 per cent), France and Italy (94 per cent) still have a very large proportion of potential party migrants.

Overall, our figures show that national voting spaces vary in their capacity to accommodate users' preferences and therefore in their capacity to represent them. Countries with a comparatively lower representative deficit are also those that potentially "lose" fewer voters. Not surprisingly, the average aggregate national representative deficit (as from Table 1 ) and the percentage of potential party migrants (as from Table 2) are indeed strongly correlated ( $r=.65, p<.001$ two-tailed, $\mathrm{N}=27)$. Figure 3 contains a scatterplot of these two measures.

\section{Figure 3. Representative deficit and percentage of potential party migrants}

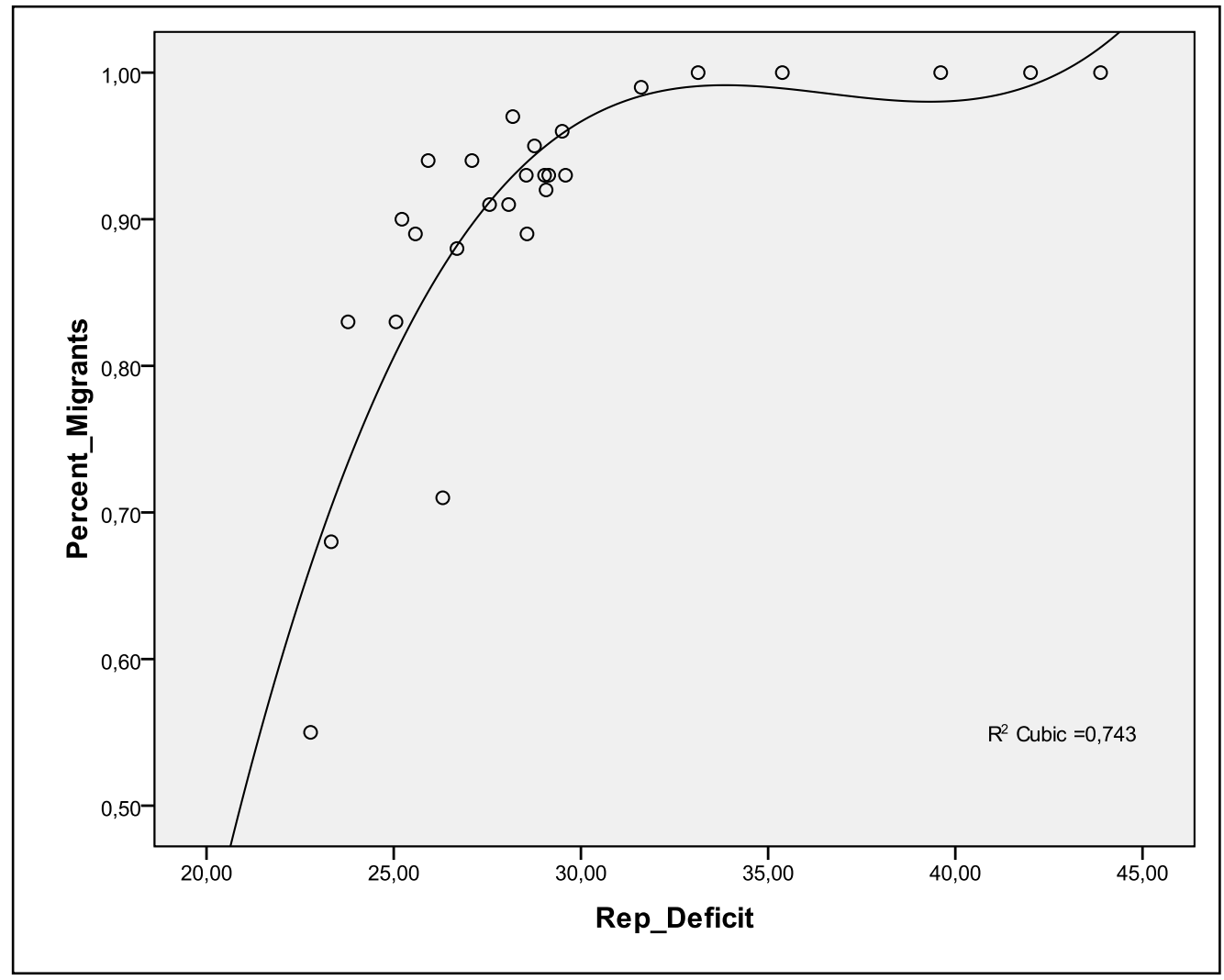

Of course, one could argue against our theoretical argument that the quality of representation is reduced as a simple function of the size of the political offer. The more parties in a country, the higher the chances for a voter to obtain a relatively low representative deficit and thus not to become a potential party migrant. According to our data, the number of parties coded by the EU Profiler team in each country is indeed correlated with the average representative deficit in the country - but only moderately so $(r=.46 ; p<.05 ; \mathrm{N}=27)$. Certainly, though it may be a necessary condition, a larger number of parties does not in itself guarantee a more diversified party offer. This might also explain why the statistical association between the number of parties and the percentage of potential party migrants in a country is rather weak $(r=.25)$ and falls short of statistical significance $(p=.21)$. In other words, better representation is not a mere result of a larger number of parties - but rather of a more diversified, richer political offer in partisan terms.

To illustrate this let us consider two examples. In most countries the EU Profiler statements divided the parties running in the elections, offering users alternatives across a wide range of positions. Some national constituencies, however, contained a more limited political offer. In Malta, for instance, every political party running in the EP 2009 elections strongly opposed the idea that euthanasia should be 
legalized; and in Denmark, every party strongly agreed with the reduction of subsidies to the EU's farmers. For Maltese citizens favoring the liberalization of euthanasia and Danish users thinking the Common Agricultural Policy of the EU was working just fine, the probability of their finding better matching representatives on these issues was increased to the extent that there were a range of parties in various other countries who also supported views of this kind. Thus, it is the diversity of the political offer that matters, not simply the number of parties running in the elections.

Despite the rather imperfect link between the number of parties in each national context and the average representative deficit, $\mathrm{H} 1$ is fully confirmed as soon as we compare a user's average national representative deficit with this same user's representative deficit if she could vote for any of the parties running throughout Europe in the EP elections. Recall that the average representative deficit in national voting districts is 27.6 per cent. When allowing a user to match her preferences with any of the 274 parties included in the EU Profiler, the average representative deficit drops by almost 7 percentage points to a value of 20.9 per cent. Figure 4 depicts this state of affairs graphically by showing the density plots for national contexts (mean value) and the European voting space.

\section{Figure 4. Representative deficit under National Voting District and a Transnational Voting District}

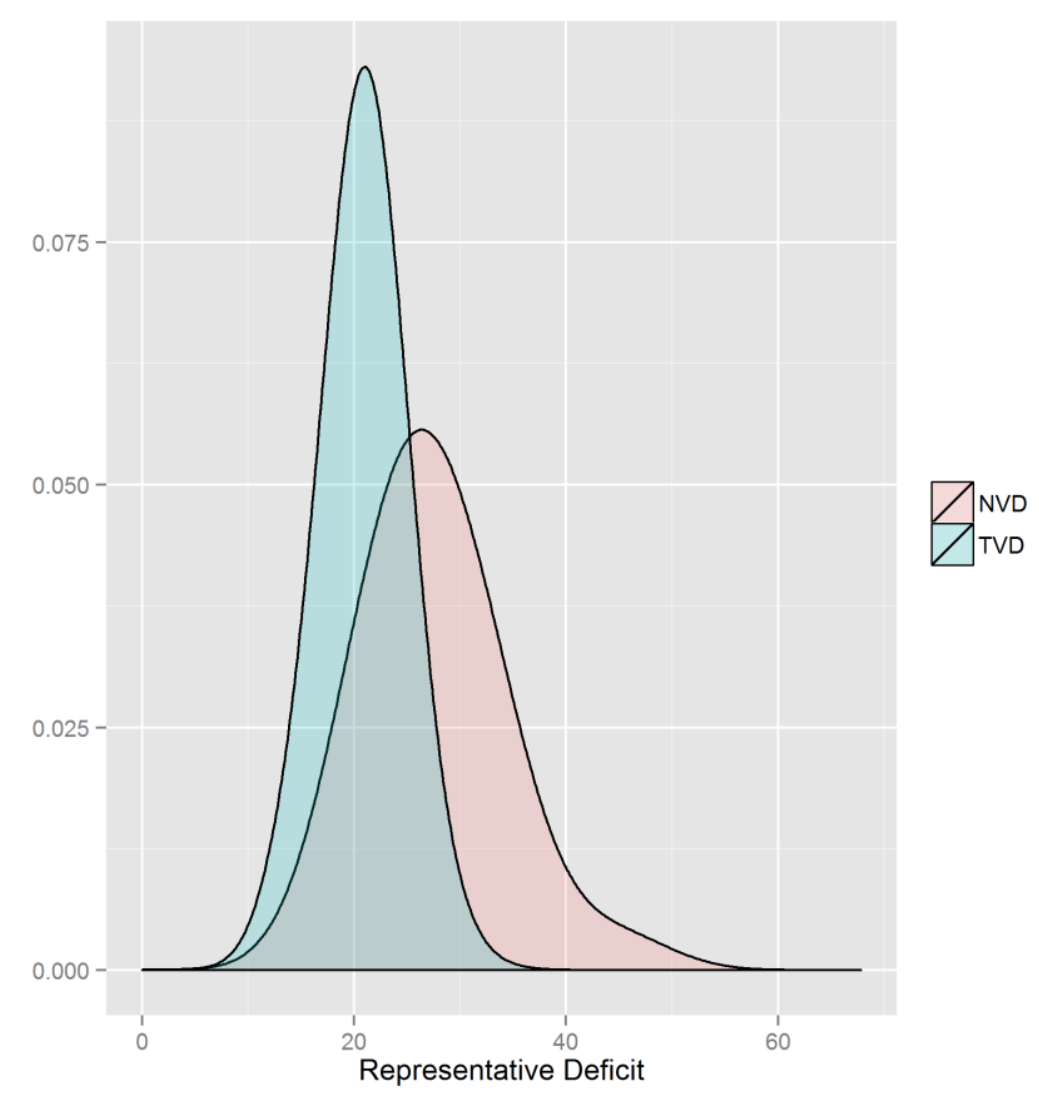

The significant reduction of the average representative deficit under a truly transnational European Voting Space (as measured by users' degree of match with their best matching party) can be further nuanced. Indeed, voters would be able to reduce their representative deficit not just by choosing one single party that matches their preferences better, but a number of them. Table 3 shows the average ranking in which the best matching party in the national context would appear if one was to choose among the 274 competing throughout Europe in the EP election. 
Table 3. Top national party rank per country in a transnational European Voting Space

\begin{tabular}{|c|c|c|c|}
\hline Country & $\begin{array}{l}\text { Average } \\
\text { Ranking }\end{array}$ & Country & $\begin{array}{l}\text { Average } \\
\text { Ranking }\end{array}$ \\
\hline Netherlands & 2.68 & France & 18.11 \\
\hline Belgium & 4.04 & Malta & 18.38 \\
\hline Bulgaria & 7.52 & Italy & 18.42 \\
\hline Denmark & 7.54 & Austria & 19.18 \\
\hline Luxembourg & 7.94 & Germany & 19.33 \\
\hline Finland & 8.71 & Estonia & 19.55 \\
\hline Greece & 11.67 & Slovenia & 23.45 \\
\hline Hungary & 11.77 & Portugal & 24.38 \\
\hline Spain & 13.04 & Ireland & 31.12 \\
\hline Czech Republic & 13.79 & Romania & 37.07 \\
\hline Cyprus & 14.28 & Slovakia & 47.32 \\
\hline Sweden & 14.49 & Lithuania & 86.37 \\
\hline United Kingdom & 16.54 & Latvia & 103.40 \\
\hline EU27 & 17.84 & Poland & 105.91 \\
\hline
\end{tabular}

On average, the best matching party in the national constituency would only appear in position 17, meaning that, on average, 16 parties competing in over seven different countries (the mean value is 7.3) match the average user's preferences better than her best-matching national party. Once again, countries with a lower average representative deficit would have less competition to fear. For instance, in the Netherlands, the average best matching party loses to "just" 1.68 parties around Europe. Conversely, in the case of Poland, the best-matching average Polish party would have to fear more than one hundred parties able to provide, potentially, for a better level of representation of Polish VAA users.

\section{Explaining active demand}

Having empirically assessed the prospect of party migrants in a transnational European voting space, we can now measure the extent to which instituting such an electoral arrangement might not only be attractive from the point of view of democratic representation but also be seen as desirable by the users of the EU Profiler. As mentioned before, one of the defining features of this pan-European VAA 
was to allow its users to assess the degree of policy congruence, not only with the parties in their own country, but also with any of the 274 parties participating in elections to the EP. To what extent did users find this feature useful? This question has been posed in the extra-questionnaire to the $E U$ Profiler. Among the over 20'000 users that completed this survey more than half considered it very (27 per cent) or somewhat (32 per cent) useful. Only a very small minority of roughly seven per cent considered this feature useless. Compared to other features of the EU Profiler, this transnational comparison ranked slightly lower, though still astonishingly high, given the impossibility for Europeans to - for the moment - cast their vote for a party outside their national voting district (see Alvarez, Levin, Trechsel \& Vassil, 2013).

The extra-questionnaire also featured an item about transnational voting. It is worth noting that 18 per cent of respondents agreed with the proposed statement "The EU Profiler made me want to vote for a party in another country". In order to understand the drivers of users' willingness to vote in a constituency outside their national one, we resorted to an estimation of a number of logistic regression models. For all models, our dependent variable is coded ' 1 ' for users who indicated their willingness to vote for a party in another country (that is, the active demanders) and ' 0 ' for all others. As a preliminary step, we estimated a structurally simple model of active demand as a function of $E U$ Profiler-related variables. The main covariate included in the model is users' representative deficit improvement moving from a nationally based voting space to a transnational European voting space, i.e., (rep. deficit in EVS - rep. deficit in NVS). According to our theoretical argument, we expect higher degrees of improvement to be positively related with the dependent variable. This preliminary model controls for users' opinion about the EU Profiler's usefulness - which we expect as well to be positively related to the willingness to vote for a party in another country. Logistic regression estimates with clustered standard errors (country level) are presented in Table 4, column 1. The results of this preliminary effort are fully in line with our expectations. Indeed, higher improvements of the representative deficit correspond to a higher likelihood to declare oneself willing to vote for a party in another European country, thus confirming H2. The coefficient of this variable is positive and highly significant $(p<.001)$. As for respondents' opinion about the tool's usefulness, this is also positively signed and statistically significant. Clearly, the tool has a stronger effect on those users who think it was useful.

To test the robustness of these findings, we estimated a number of progressively more complex models that take into account socio-demographic characteristics of the users (column 2), measures about their informational sources, interest in political matters (column 3) and attitudes towards democracy at both national and EU level (column 4). 
Table 4. The individual-level determinants of active demand

\begin{tabular}{|c|c|c|c|c|}
\hline & $(1)$ & $(2)$ & (3) & (4) \\
\hline \multirow[t]{2}{*}{ Rep. Deficit Improve } & .043 & .035 & .036 & .033 \\
\hline & $(.006)^{* * *}$ & $(.007)^{* * *}$ & $(.006)^{* * *}$ & $(.005)^{* * *}$ \\
\hline \multirow[t]{2}{*}{ EU Profiler was useful } & .242 & .217 & .198 & .220 \\
\hline & $(.076)^{* *}$ & $(.074)^{* *}$ & $(.071)^{* *}$ & $(.072)^{* *}$ \\
\hline \multirow[t]{2}{*}{ Gender $($ Female $=1)$} & - & -.560 & -.534 & -.508 \\
\hline & & $(.064)^{* * *}$ & $(.059) * * *$ & $(.064)^{* * *}$ \\
\hline \multirow[t]{2}{*}{ Age } & - & -.024 & -.024 & -.025 \\
\hline & & $(.002)^{* * *}$ & $(.002)^{* * *}$ & $(.002) * * *$ \\
\hline \multirow[t]{2}{*}{ Education } & - & .112 & .109 & .110 \\
\hline & & $(.024)^{* * *}$ & $(.022) * * *$ & $(.023) * * *$ \\
\hline \multirow[t]{2}{*}{ Income } & - & -.030 & -.031 & -.014 \\
\hline & & $(.023)$ & $(.023)$ & $(.018)$ \\
\hline \multirow[t]{2}{*}{ Religious Attendance } & - & -.060 & -.065 & -.062 \\
\hline & & $(.027)^{*}$ & $(.025)^{* *}$ & $(.025)^{*}$ \\
\hline \multirow[t]{2}{*}{ Years of Residence } & - & .000 & -.000 & .000 \\
\hline & & $(.000)$ & $(.000)$ & $(.000)$ \\
\hline \multirow[t]{2}{*}{ Urbanization } & - & .018 & .009 & .006 \\
\hline & & $(.025)$ & $(.024)$ & $(.025)$ \\
\hline \multirow[t]{2}{*}{ Interest in Politics } & - & - & .076 & .070 \\
\hline & & & $(.062)$ & $(.063)$ \\
\hline \multirow[t]{2}{*}{ Interest in EP Campaign } & - & - & .153 & .168 \\
\hline & & & $(.068)^{*}$ & $(.064)^{* *}$ \\
\hline \multirow[t]{2}{*}{ Political Complexity } & - & - & .024 & .021 \\
\hline & & & $(.025)$ & $(.022)$ \\
\hline \multirow[t]{2}{*}{ Index of Media Use } & - & - & .019 & .011 \\
\hline & & & $(.025)$ & $(.024)$ \\
\hline \multirow[t]{2}{*}{ Satisf. Democracy (National) } & - & - & - & -.286 \\
\hline & & & & $(.047)^{* * *}$ \\
\hline \multirow[t]{2}{*}{ Satisf. Democracy (EU) } & - & - & - & .031 \\
\hline & & & & $(.045)$ \\
\hline \multirow[t]{2}{*}{ Constant } & -1.906 & -1.064 & -1.620 & -1.265 \\
\hline & $(.099)^{* * *}$ & $(.199)^{* * *}$ & $(.239)^{* * *}$ & $(.272)$ \\
\hline $\mathrm{N}$ & 18773 & 15621 & 14924 & 14749 \\
\hline Log-likelihood & -8833.8 & -7148.5 & -6847.9 & -6705.3 \\
\hline
\end{tabular}


The socio-demographic controls include respondents' gender, age, educational level, income, religious attendance, years of residence in that country, and degree of urbanization of their town of residence. The coefficient of the representative deficit improvement barely budges, and stays as significant as in the simpler model from column 1.

A number of further interesting findings emerge from the coefficients relative to the sociodemographic variables. Some controls - income, years of residence in the country and degree of urbanization - fail to bear any statistically significant effect on the dependent variable. For the others, however, we find significant effects that go in the expected direction, allowing us to identify the profile of voters that are potentially more likely to be among active demanders: male, young, and highly educated. Finally, the stronger one's attachment to a parish, as expressed by the frequency of attendance of religious services, the less attractive becomes a vote-migration beyond one's national borders.

The inclusion of further controls related to users' informational sources and interest in politics (column 3) do not alter the conclusions drawn so far in any tangible way. As compared to sociodemographic measures, however, the variables included in this block do not appear to play much of a role in our understanding of active demand for transnational voting. Both users' perception of the complexity of the political reality and their frequency of media use for political information are positively signed but fall short of statistical significance. Interest in politics is as well not statistically significant, whereas interest in the European election campaign is. In other words, voters' interest in politics is not enough for generating active demand for transnational voting rights whereas having an interest in European politics does play a role.

Finally, we controlled for users' degree of satisfaction with democracy, at both national and EU levels, under the expectation that the willingness to cast a vote outside one's national context is fostered by higher degrees of satisfaction with EU democracy and hindered by lower degrees of satisfaction with democracy at the national level. The estimated coefficients are in both cases signed as expected. However, only in the case of satisfaction with national democracy we find a statistically significant effect. The effect of our variable of foremost interest (i.e., representative deficit improvement) remains virtually unchanged and strong nonetheless. ${ }^{1}$

The results of model 4 are further explored in Figure 5, which plots estimations from model 4 against increasing values of our key independent variable (the improvement in representation which would result from a transnational voting space). All other variables are held at their mean value in the plot.

1 To test the robustness of these findings, we also controlled for a number of macro-level factors such as countries' geographical location (East/West) and the respective party systems' size. None of these variables achieve statistical significance at conventional levels, and the model estimates remain in every case virtually unchanged. The results of these further checks are not shown for clarity of presentation. 


\section{Figure 5. Relationship between representative improvement and likelihood of voting for a party} in another country

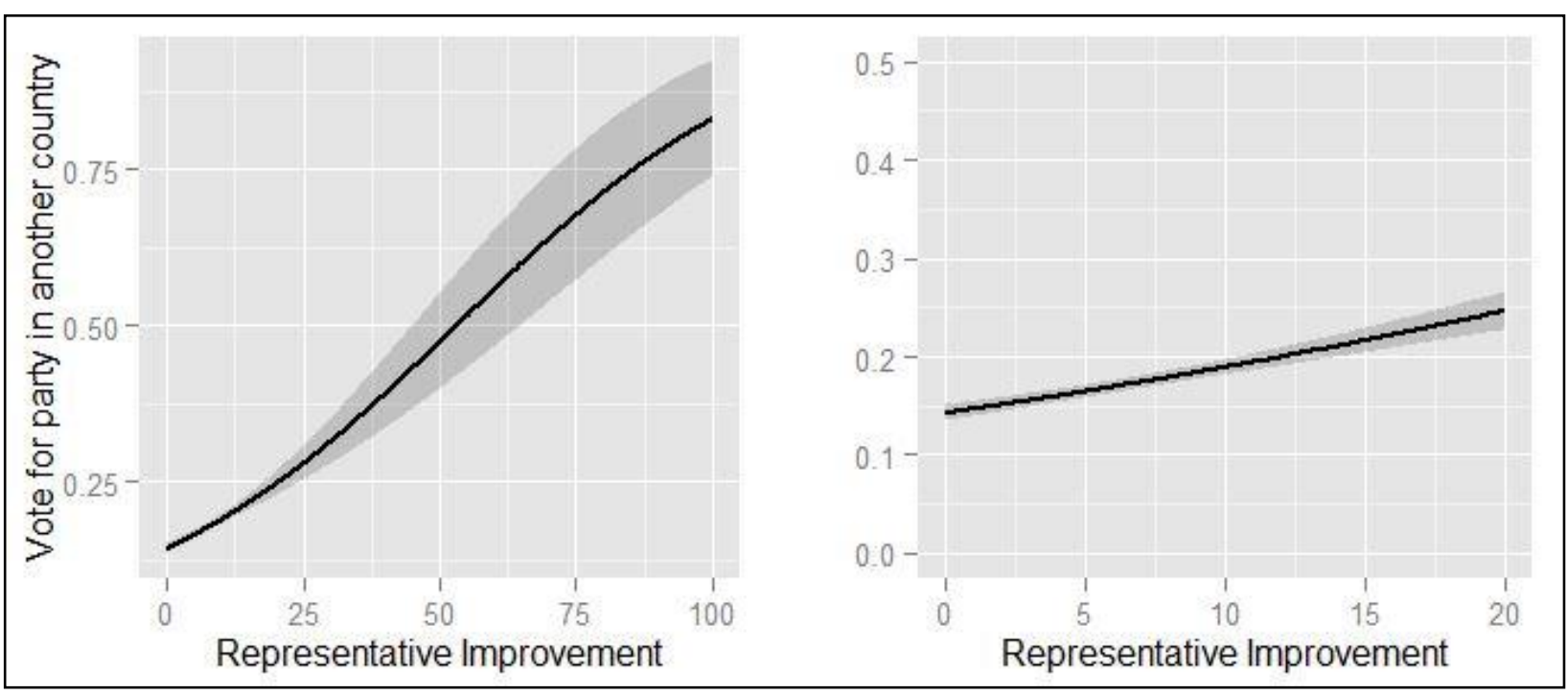

The left side of Figure 5 shows the full potential range of the improvement in representation, from 0 to 100: we estimate that a change of this magnitude would increase an individual's likelihood of wanting to vote for a party in another country by approximately 70 percentage points. To be sure, the majority of individuals would experience a much lower representative improvement (as few individuals have a ' 0 ' representation). In our data, the overwhelming proportion of users sees their representation improve between 0 and 20 points (hence our confidence interval widens after this point). The right side of Figure 5 therefore focuses more specifically on these observations, showing that the likelihood of vote migration increases by approximately one percentage point for every two points of representative improvement. On the basis of this evidence, we can conclude that there is a significant positive correlation between whether an individual would consider voting for a party in another country and the extent to which they might be better represented if they did so. This demonstrates that, were Europe's voting space to be trans-nationalised, those potentially making use of such an opportunity, would be those most likely to directly benefit from it.

\section{Conclusions}

The European Union finds itself under enormous pressure generated by the financial and economic crisis, the problems of the Eurozone, but also growing Euroskepticism among its citizens (Habermas 2012; Rose 2013). In this context, to curate and even foster the democratic legitimacy conveyed by the electorate to the European Parliament in regular, continent-wide and simultaneously held elections becomes an ever more pressing issue. Of the various proposals put forward to improve the quality of democratic representation and citizen participation in EU politics we have chosen to develop a view put forward by MEP Andrew Duff that promotes an additional 25 seats in the European Parliament which must be won by Europarties in a single European constituency. The goal of this proposal is to reduce the state-centric character of representation in the European Union by creating a direct link between MEPs and the electorate in its entirety. While we believe that striving towards this goal is desirable from a normative point of view, we have argued that Europarties, in their current format and functioning, are not the ideal vehicles for the implementation of Duff's proposal. They are, for the time being, mere federations of national parties, proposing platforms characterised by minimal common denominators rather than detailed, clear and comprehensive policy positions. Instead, we offer a normative proposal, arguing that a transnational European voting space is achievable through a 
combination of institutional reform - allowing voters to cast votes beyond their national constituencies - and technological innovation in the form of a pan-European voting advice application. This combination would go some way to alleviating the stress placed on electoral representation in Europe by the state-centric and lingua-centric properties characterising its polity of ignorance, without having to rely on weak and vague Europarties competing across an entire continent.

We back this normative proposal by empirically testing two underlying hypothesis. First, our analyses of the 2009 EU Profiler VAA show that a wide, transnational partisan offer increases the probability of the average voter's aggregate political stances to be matched by a political party. If a user of this VAA had been able to choose a party from any EU member state, her representative deficit would have significantly decreased. Second, the demand for casting a transnational vote among users is first and foremost driven by this potential decrease in their representative deficit: the better the potential match with a party competing beyond the borders of one's national constituency, the higher the probability of this citizen to actually desire casting a vote for this "foreign" party.

It is apparent from his account that Andrew Duff considers the addition of 25 transnational seats to the European Parliament to exhibit a gradualist approach in the sense that its successful implementation could lead to an expansion of the transnational electoral district and still further Europeanisation of EP elections. Though we doubt the capacity of Europarties in their current manifestations to effectively contribute to this agenda, the approach advocated here does not eschew the possibility of a transnational European voting space becoming gradually more robust. If voters were to perceive themselves as better represented given the opportunity to vote for parties outside their national districts, there would be significant growth potential for a voting space of this kind. And, indeed, the more developed a transnational voting space becomes the further we may move from a polity whose citizens are largely ignorant of one another's perspectives to a polity of transnational awareness where citizens link themselves to the political context of other member states 


\section{References}

Alvarez, R. Michael, Levin, Inés, Trechsel, Alexander H. and Kristjan Vassil. 2013. "Voting Advice Applications: How Useful and For Whom?", Journal of Information Technology and Politcs, article in press.

Alvarez, R. Michael, Levin, Inés, Mair, Peter and Alexander H. Trechsel. 2013. "Party preferences in the digital age: The impact of Voting Advice Applications", Party Politics, article in press.

Brito Vieira, Monica and David Runciman. 2008. Representation. Cambridge: Polity Press.

Cedroni, Lorella and Diego Garzia (eds). 2010. Voting Advice Applications in Europe: The State of the Art. Naples: Civis.

Duff, Andrew. 2010. Draft Report on a proposal for a modification of the Act concerning the election of Members of the European Parliament by direct universal suffrage of 20 September 1976 (2010/XXXX(INI))

Garzia, Diego, Alexander H. Trechsel, Kristjan Vassil and Elias Dinas. 2013. "Indirect Campaigning Past, Present and Future of Voting Advice Applications". In Bernie Grofman, Alexander H. Trechsel and Mark Franklin (eds.), The Internet and Democracy in Global Perspective: Voters, Candidates, Parties, and Social Movements. New York: Springer.

Garzia, Diego and Stefan Marshall. 2012. Voting Advice Applications Under Review - The State of the Research. International Journal of Electronic Governance 5(3/4), pp. 203-222.

Habermas, Jürgen, 2012. The Crisis of the European Union. A Response. London: Polity.

Hix, Simon. 2008. What's Wrong with the European Union and How to Fix it. London: Polity.

Hix, Simon and Michael Marsh. 2011. "Second-order Effects Plus Pan-European Political Swings: An Analysis of European Parliament Elections across Time". Electoral Studies, 30, pp. 4-15.

Kymlicka, Will. 2001. Politics in the Vernacular: Nationalism, Multiculturalism and Citizenship. Oxford: Oxford University Press.

Lacey, Joseph. 2013. Must Europe be Swiss? On the Idea of a Voting Space and the Possibility of a Multilingual Demos. British Journal of Political Science, article in press.

Mair, Peter. 2000. The Limited Impact of Europe on National Party Systems. West European Politics, 23 (4), pp. 27-51.

Marschall, Stefan and Christian K. Schmidt. 2010. "The impact of voting indicators: the case of the German Wahl-O-Mat", in Lorella Cedroni and Diego Garzia (eds.), Voting Advice Applications in Europe: The State of the Art. Naples: Civis, pp. 65-104.

Pitkin, Hanna. 1967. The Concept of Representation. Berkeley: University of California Press.

Reif, Karlheinz and Hermann Schmitt, 1980. "Nine second-order national elections - a conceptual framework for the analysis of European election results", EJPR 8(1), pp. 3-44.

Rose, Richard, 2013. Representing Europeans: A Pragmatic Approach. Oxford: Oxford University Press.

Trechsel, Alexander H. and Peter Mair. 2011. "When parties (also) position themselves: An introduction to the EU Profiler". Journal of Information Technology \& Politics 8(1), pp. 1-20.

Urbinati, Nadia. 2006. Representative Government: Principles and Genealogy. Chicago: University of Chicago Press.

Young, Iris Marion. 2000. Inclusion and Democracy. Oxford: Oxford University Press. 


\section{APPENDIX - Coding of the independent variables included in the regression analysis}

Rep. Deficit Improve

EU Profiler was useful

Gender

Age

Education

Income

Religious Attendance

Years of Residence

Urbanization

Interest in Politics

Interest in EP Campaign

Political Complexity

Index of Media Use

Satisf. Democracy (National)

Satisf. Democracy (EU) scale from 0 (no improve) to 100 (maximum possible improve)

no (0) yes (1)

male (0) female (1)

in years

pre-primary education (0) primary education (1) lower secondary education (2) upper secondary education (3) postsecondary non tertiary education (4) first stage of tertiary education (5) second stage of tertiary education (6)

0-500 Euros (0) 500-1000 Euros (1) 1000-1500 Euros (2) 1500-2000 Euros (3) 2000-3000 Euros (4) 3000-4000 Euros (5) 4000-6000 Euros (6) 6000-10000 Euros (7) more than 10000 Euros (8)

never (0) once a year or less (1) a few times a year (2) once a month (3) once a week (4) several times a week (5)

in years

rural area or village (0) small or middle-sized town (1) suburbs of large town or city (2) large town or city (3)

not at all (0) a little (1) somewhat (2) very (3)

not at all (0) a little (1) somewhat (2) very (3)

never (0) seldom (1) occasionally (2) regularly (3) frequently (4)

scale from 1 (lowest) to 10 (highest)

not at all (0) not very (1) fairly (2) very (3)

not at all (0) not very (1) fairly (2) very (3) 


\section{Author contacts:}

\section{Jonathan Bright}

University of Oxford

1 St Giles

Oxford OX1 3JS

United Kingdom

Email: jonathan.bright@oii.ox.ac.uk

\section{Diego Garzia \\ Joseph Lacey}

Alexander H. Trechsel (Correspondence author)

European University Institute

Via dei Roccettini 9

50014 San Domenico di Fiesole

Italy

Email: Diego.Garzia@eui.eu; Joseph.Lacey@eui.eu; Alexander.Trechsel@eui.eu 